\title{
Atmospheric $\mathrm{H}_{2} \mathrm{~S}$ : Impact on Plant Functioning
}

\author{
Ties Ausma* and Luit J. De Kok \\ Laboratory of Plant Physiology, Groningen Institute for Evolutionary Life Sciences, University of Groningen, \\ Groningen, Netherlands
}

Hydrogen sulfide $\left(\mathrm{H}_{2} \mathrm{~S}\right)$ is an air pollutant present at high levels in various regions. Plants actively take up $\mathrm{H}_{2} \mathrm{~S}$ via the foliage, though the impact of the gas on the physiological functioning of plants is paradoxical. Whereas elevated $\mathrm{H}_{2} \mathrm{~S}$ levels may be phytotoxic, $\mathrm{H}_{2} \mathrm{~S}$ levels realistic for polluted areas can also significantly contribute to the sulfur requirement of the vegetation. Plants can even grow with $\mathrm{H}_{2} \mathrm{~S}$ as sole sulfur source. There is no relation between the rate of $\mathrm{H}_{2} \mathrm{~S}$ metabolism and the $\mathrm{H}_{2} \mathrm{~S}$ susceptibility of a plant, which suggests that the metabolism of $\mathrm{H}_{2} \mathrm{~S}$ does not contribute to the detoxification of absorbed sulfide. By contrast, there may be a strong relation between the rate of $\mathrm{H}_{2} \mathrm{~S}$ metabolism and the rate of sulfate metabolism: foliar $\mathrm{H}_{2} \mathrm{~S}$ absorbance may downregulate the metabolism of sulfate, taken up by the root. Studies with plants from the Brassica genus clarified the background of this downregulation. Simultaneously, these studies illustrated that $\mathrm{H}_{2} \mathrm{~S}$ fumigation may be a useful tool for obtaining insight in the regulation of sulfur homeostasis

OPEN ACCESS

Edited by:

Karl H. Mühling,

University of Kiel, Germany

Reviewed by:

Ruediger Hell,

Universität Heidelberg, Germany

Elke Bloem,

Julius Kühn-Institut, Germany

*Correspondence:

Ties Ausma

t.ausma@rug.n

Specialty section:

This article was submitted to Plant Nutrition,

a section of the journal Frontiers in Plant Science

Received: 25 March 2019

Accepted: 20 May 2019

Published: 11 June 2019

Citation:

Ausma T and De Kok LJ (2019)

Atmospheric $\mathrm{H}_{2} \mathrm{~S}$ : Impact on

Plant Functioning.

Front. Plant Sci. 10:743.

doi: 10.3389/fp/s.2019.00743 and the (signal) functions of sulfur-containing compounds in plants.

Keywords: air pollution, hydrogen sulfide, sulfur metabolism, glutathione, Brassica

\section{INTRODUCTION}

Hydrogen sulfide $\left(\mathrm{H}_{2} \mathrm{~S}\right)$ is a gaseous compound present in the global atmosphere (Watts, 2000). Together with sulfur dioxide $\left(\mathrm{SO}_{2}\right)$ and a variety of organo-sulfur gases, $\mathrm{H}_{2} \mathrm{~S}$ plays a pivotal role in shaping the earth's climate (Sipilä et al., 2010; Perraud et al., 2015). The gas naturally originates from volcanoes and geothermal vents as well as from wetlands, salt marshes and estuaries, where it is produced by bacteria during the anaerobic decay of organic sulfur compounds (Kanda and Tsuruta, 1995; Watts, 2000; Stern, 2005). The estimated natural emission of $\mathrm{H}_{2} \mathrm{~S}$ is $4.4 \mathrm{Tg}$ per year, which is only a small fraction of the total natural sulfur gas emission, estimated at $52 \mathrm{Tg}$ per year (Watts, 2000). $\mathrm{SO}_{2}$ and dimethylsulfide (DMS) make up the majority of this emission: 23 and $24.5 \mathrm{Tg}$ per year, respectively (Watts, 2000; Carn et al., 2017). Besides from natural sources, atmospheric $\mathrm{H}_{2} \mathrm{~S}$ originates from livestock production and industrial processes, such as the combustion of biomass and fossil fuels (Watts, 2000). The anthropogenic emission of sulfur gases is exceeding the natural sulfur gas emission and is currently estimated at 70-100 Tg per year (Klimont et al., 2013; Fioletov et al., 2016). Most of this sulfur is emitted as $\mathrm{SO}_{2}$, though approximately $3 \mathrm{Tg}$ per year is emitted as $\mathrm{H}_{2} \mathrm{~S}$ (Klimont et al., 2013; Fioletov et al., 2016).

The residence time of emitted $\mathrm{H}_{2} \mathrm{~S}$ in the atmosphere is short (approximately 15 days), since $\mathrm{H}_{2} \mathrm{~S}$ is rapidly oxidized by hydroxyl radicals and other atmospheric oxidants to $\mathrm{SO}_{2}$ and finally sulfate (Trudinger, 1986). Consequently, in rural areas, $\mathrm{H}_{2} \mathrm{~S}$ concentrations are ranging between 0.02 and $0.3 \mathrm{nl} \mathrm{L}^{-1}$ (Kellogg et al., 1972; Slatt et al., 1978; Beauchamp et al., 1984). 
However, in regions with volcanic activity and in regions with polluting industrial or livestock production, $\mathrm{H}_{2} \mathrm{~S}$ concentrations may easily surpass the odor threshold level of $0.02 \mu \mathrm{L}^{-1}$ (resulting in a distinct rotten egg smell; Beauchamp et al., 1984). Moreover, in the close vicinity of volcanoes and geothermal wells, atmospheric $\mathrm{H}_{2} \mathrm{~S}$ concentrations may even exceed $0.1 \mu \mathrm{L}^{-1}$ (Ernst, 1997; Schulte et al., 1997; Baillie et al., 2016).

The impact of elevated $\mathrm{H}_{2} \mathrm{~S}$ levels on plants is paradoxical. Although high atmospheric $\mathrm{H}_{2} \mathrm{~S}$ concentrations may negatively affect plant growth and survival, the foliar uptake of $\mathrm{H}_{2} \mathrm{~S}$ may also substantially contribute to plant sulfur nutrition (De Kok, 1990; De Kok et al., 2007). This concise review presents an overview of the impact of atmospheric $\mathrm{H}_{2} \mathrm{~S}$ on the physiological functioning of plants.

\section{UPTAKE AND EMISSION OF $\mathrm{H}_{2} \mathrm{~S}$ BY PLANTS}

Atmospheric $\mathrm{H}_{2} \mathrm{~S}$ may be adsorbed at the leaf's surface, though $\mathrm{H}_{2} \mathrm{~S}$ uptake mainly occurs via stomata: the cuticle is hardly permeable for gases (Lendzian, 1984). The rate of foliar gas uptake can be described by Fick's law of diffusion: $J=\Delta c \times g$. In this equation, $J$ represents the rate of gas uptake by the shoot $\left(\mu \mathrm{mol} \mathrm{cm} \mathrm{cm}^{-2} \mathrm{~s}^{-1}\right), \Delta c$ the concentration gradient of the gas between the atmosphere and the shoot's interior $\left(\mu \mathrm{mol} \mathrm{cm} \mathrm{cm}^{-3}\right)$, and $g$ the diffusive conductance of the shoot to the gas ( $\mathrm{cm} \mathrm{s}^{-1}$; Nobel, 1983; De Kok and Tausz, 2001; De Kok et al., 2007). The diffusive conductance of the shoot is predominantly determined by stomatal conductance and mesophyll conductance (Nobel, 1983; De Kok and Tausz, 2001; De Kok et al., 2007). Whereas stomatal conductance depends on the extent of stomatal aperture, mesophyll conductance depends on the physical and biochemical characteristics of a gas, viz. its solubility in the aqueous phase of the mesophyll, its reactivity with cellular components and in case of some gases (e.g., $\mathrm{CO}_{2}$ ) its rate of metabolism (Nobel, 1983; De Kok and Tausz, 2001; De Kok et al., 2007). The diffusive conductance of the shoot is frequently expressed in $\mathrm{mmol} \mathrm{m} \mathrm{m}^{-2} \mathrm{~s}^{-1}$. For conversion to $\mathrm{cm} \mathrm{s}^{-1}$, the volume of $1 \mathrm{~mol}$ of a gas at 1 atm and $20^{\circ} \mathrm{C}$ is $24.06 \mathrm{dm}^{3}$ (Nobel, 1983). This corresponds to $41.6 \mathrm{~mol} \mathrm{~m}^{-3}$. Therefore, a gas conductance of $1 \mathrm{~cm} \mathrm{~s}^{-1}$ at 1 atm and $20^{\circ} \mathrm{C}$ equals $41.6 \mathrm{~mol} \mathrm{~m} \mathrm{~m}^{-3} \times 0.01 \mathrm{~m} \mathrm{~s}^{-1}=416 \mathrm{mmol} \mathrm{m} \mathrm{m}^{-2} \mathrm{~s}^{-1}$.

The uptake of $\mathrm{H}_{2} \mathrm{~S}$ by plant shoots follows distinct kinetics, which greatly differ from the kinetics observed for other sulfur gases. For instance, $\mathrm{SO}_{2}$ uptake rates generally increase linearly with atmospheric $\mathrm{SO}_{2}$ concentration (Tausz et al., 1998; Van der Kooij and De Kok, 1998; De Kok and Tausz, 2001). Stomatal conductance is limiting $\mathrm{SO}_{2}$ uptake rates, since the diffusive conductance of the shoot to $\mathrm{SO}_{2}$ is often close to the stomatal conductance for water vapor (Tausz et al., 1998; Van der Kooij and De Kok, 1998; De Kok and Tausz, 2001). In accordance with this, the mesophyll conductance to $\mathrm{SO}_{2}$ is high and therefore not limiting uptake rates. $\mathrm{SO}_{2}$ has a high solubility in the aqueous phase of the mesophyll: it has a rather high Henry's law solubility constant of $1.23 \mathrm{M} / \mathrm{atm}$ at $25^{\circ} \mathrm{C}$ (De Bruyn et al., 1995). Moreover, it rapidly reacts with mesophyll water, resulting in the formation of sulfurous acid (Tausz et al., 1998).

In contrast to $\mathrm{SO}_{2}, \mathrm{H}_{2} \mathrm{~S}$ uptake rates follow saturation kinetics with respect to the atmospheric $\mathrm{H}_{2} \mathrm{~S}$ level (Figure 1; De Kok et al., 2002, 2007, 2009). These kinetics, which can be described by the Michaelis-Menten equation, are controlled by mesophyll conductance (Figure 1). At non-saturating atmospheric $\mathrm{H}_{2} \mathrm{~S}$ levels, uptake rates increase linearly with external $\mathrm{H}_{2} \mathrm{~S}$ concentration, since stomatal conductance is not affected upon exposure to $\mathrm{H}_{2} \mathrm{~S}$ concentrations $<1 \mu \mathrm{L} \mathrm{L}^{-1}$ (De Kok et al., 1989, 1991, 1997). However, at saturating atmospheric $\mathrm{H}_{2} \mathrm{~S}$ levels, mesophyll conductance prevents further increments in $\mathrm{H}_{2} \mathrm{~S}$ uptake rates (De Kok et al., 1989, 1991, 1997).

It is evident that at the $\mathrm{pH}$ of mesophyll cells (between 5 and 6.4) absorbed $\mathrm{H}_{2} \mathrm{~S}$ remains largely undissociated $\left(\mathrm{H}_{2} \mathrm{~S} \rightarrow \mathrm{HS}^{-}+\mathrm{H}^{+} ; \mathrm{p} K_{\mathrm{a}}=7.0\right)$, causing it to easily pass cellular membranes (Cope and Spedding, 1982; Mathai et al., 2009; Riahi and Rowley, 2014). $\mathrm{H}_{2} \mathrm{~S}$ is only slightly soluble in the mesophyll: it has a Henry's law solubility constant of $0.086 \mathrm{M} / \mathrm{atm}$ at $25^{\circ} \mathrm{C}$ (De Bruyn et al., 1995). However, mesophyll conductance appears to be strictly controlled by the rate of sulfide metabolism in the amino acid cysteine (De Kok et al., 1989, 1991, 1998). After absorbance, $\mathrm{H}_{2} \mathrm{~S}$ is incorporated with very high affinity in cysteine via the reaction of sulfide with $O$-acetylserine (OAS), catalyzed by the enzyme O-acetylserine(thiol)lyase (OAS-TL; De Kok et al., 2007, 2009). The activity of OAS-TL, the affinity of the enzyme for sulfide and the availability of OAS determine mesophyll conductance (De Kok et al., 2007, 2009). Consequently, in spinach (Spinacia oleracea) $\mathrm{H}_{2} \mathrm{~S}$ uptake rates were, in contrast to $\mathrm{SO}_{2}$ uptake rates, strongly dependent on shoot temperature with lower uptake rates at lower temperatures (De Kok et al., 1991). Moreover, in spinach, the maximum $\mathrm{H}_{2} \mathrm{~S}$ uptake rate $\left(\mathrm{JH}_{2} \mathrm{~S}_{\max }\right)$ could be enhanced by the direct supply of OAS

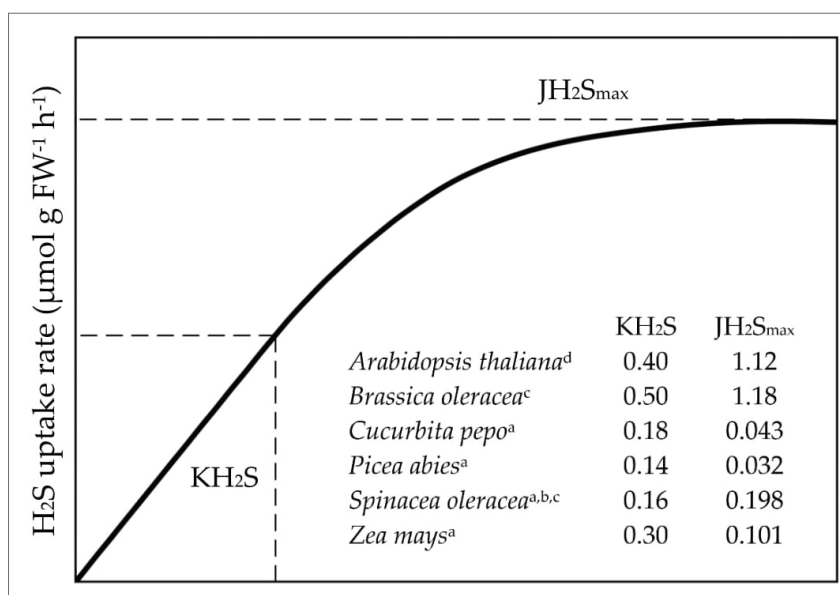

Atmospheric $\mathrm{H}_{2} \mathrm{~S}$ concentration $\left(\mu \mathrm{l}^{-1}\right)$

FIGURE 1 | The kinetics of foliar $\mathrm{H}_{2} \mathrm{~S}$ uptake. $\mathrm{JH}_{2} \mathrm{~S}_{\max }$ represents the maximum uptake rate of $\mathrm{H}_{2} \mathrm{~S}$ and $\mathrm{KH}_{2} \mathrm{~S}$ the concentration at which $1 / 2 \mathrm{JH}_{2} \mathrm{~S}_{\text {max }}$ is reached. FW: fresh weight. Figure modified after De Kok et al. (2002). Data derived from

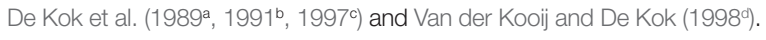


to foliar tissue (Buwalda et al., 1992). Notably, a second cysteine-producing reaction may further determine mesophyll conductance. Cysteine desulfhydrases (DES) have significance in the degradation of cysteine, which results in the endogenous release of sulfide (Schütz et al., 1991). However, circumstantial evidence suggests that the reverse reaction may be relevant for foliar $\mathrm{H}_{2} \mathrm{~S}$ absorbance: in leaf homogenates of cucurbit plants (Cucurbita pepo spp.) DES assimilated atmospheric $\mathrm{H}_{2} \mathrm{~S}$ in cysteine by using ammonia and pyruvate as substrates (Schütz et al., 1991). Nevertheless, the significance of this reaction for intact plants remains to be studied (De Kok et al., 1998, 2007).

Maximum $\mathrm{H}_{2} \mathrm{~S}$ uptake rates and $\mathrm{KH}_{2} \mathrm{~S}$ values (viz. the $\mathrm{H}_{2} \mathrm{~S}$ concentration at which $1 / 2 \mathrm{JH}_{2} \mathrm{~S}_{\max }$ is reached) differ considerably among species (Figure 1; De Kok et al., 2002). For example, whereas measured $\mathrm{KH}_{2} \mathrm{~S}$ values ranged from 0.14 to $0.50 \mu \mathrm{L}^{-1}$ $\mathrm{H}_{2} \mathrm{~S}$, maximum $\mathrm{H}_{2} \mathrm{~S}$ uptake rates varied between 0.03 and $1.18 \mu \mathrm{mol} \mathrm{H}_{2} \mathrm{~S} \mathrm{~g} \mathrm{FW}^{-1} \mathrm{~h}^{-1}$ (Figure 1). This variation corresponded with variation in the rate of sulfide incorporation in cysteine (De Kok et al., 2007). However, it remains elusive to what extent it also coincides with variation in sulfur growth requirement among species. It is unknown if, for instance, species with a high sulfur demand also have high $\mathrm{H}_{2} \mathrm{~S}$ uptake efficiencies.

Besides $\mathrm{H}_{2} \mathrm{~S}$ uptake, plants may also emit $\mathrm{H}_{2} \mathrm{~S}$. It has been suggested that emission of $\mathrm{H}_{2} \mathrm{~S}$ to the atmosphere has significance in regulating sulfur homeostasis (Schröder, 1993). Plants may, temporarily, emit elevated levels of $\mathrm{H}_{2} \mathrm{~S}$ via their foliage into the atmosphere when exposed to excess sulfur in the form of $\mathrm{SO}_{2}$, sulfate or cysteine (Rennenberg, 1984; De Kok, 1990; Schröder, 1993; Bloem et al., 2007). For instance, depending on the atmospheric $\mathrm{SO}_{2}$ level, up to $15 \%$ of foliarly absorbed $\mathrm{SO}_{2}$ could be re-emitted as $\mathrm{H}_{2} \mathrm{~S}$ (De Kok, 1990). However, to what extent $\mathrm{H}_{2} \mathrm{~S}$ evolution has significance in regulating sulfur homeostasis in the absence of excess sulfur is unclear. If plants were grown with a normal sulfur supply, the $\mathrm{H}_{2} \mathrm{~S}$ evolution rate generally constituted a negligible fraction of the total sulfur assimilation rate (Stulen and De Kok, 1993). For instance, in spruce (Picea abies), this fraction was less than $0.1 \%$ (Rennenberg et al., 1990). More likely, the rate of foliar $\mathrm{H}_{2} \mathrm{~S}$ emission just reflects the rate of sulfate reduction as well as the activity and sulfide-affinity of the cysteine synthesizing and degrading enzymes (viz. OAS-TL and DES, possibly together with other enzymes; Hell et al., 2002). Irrespective of this, minute $\mathrm{H}_{2} \mathrm{~S}$ emission levels might still have physiological significance in, for instance, plant stress protection. Emitted $\mathrm{H}_{2} \mathrm{~S}$ might possibly degrade leaf surface ozone $\left(\mathrm{O}_{3}\right.$; Schnug, 1997; Haneklaus et al., 2007). Furthermore, $\mathrm{H}_{2} \mathrm{~S}$ emission may have importance in the defense of plants against pathogen attacks (Bloem et al., 2007; Haneklaus et al., 2007).

\section{PHYTOTOXICITY OF $\mathrm{H}_{2} \mathrm{~S}$}

The foliar absorbance of atmospheric $\mathrm{H}_{2} \mathrm{~S}$ may negatively affect plant functioning. $\mathrm{H}_{2} \mathrm{~S}$ is a very reactive compound and, similar to cyanide, it complexes with high affinity to the metallo-groups in proteins (Mudd, 1979; Beauchamp et al., 1984; Martin and Maricle, 2015). In several plants, exposure to $\mathrm{H}_{2} \mathrm{~S}$ inhibited respiration, which could be explained by the reaction of $\mathrm{H}_{2} \mathrm{~S}$ with the heme-group of cytochrome $c$ oxidase (Martin and Maricle, 2015). Additionally, in various plants the presence of $\mathrm{H}_{2} \mathrm{~S}$ repressed the activity of a broad group of (likely heme-containing) NADH-oxidizing enzymes (Maas and De Kok, 1988). Notably, these repressions may directly result in a lower plant growth and survival, but also indirectly: by disturbing energy homeostasis, $\mathrm{H}_{2} \mathrm{~S}$ presence may increase the susceptibility of plants for other environmental stressors. For instance, exposure to $0.25 \mu \mathrm{L} \mathrm{L}^{-1} \mathrm{H}_{2} \mathrm{~S}$ decreased the freezing tolerance of the foliage of winter wheat (Triticum aestivum; Stuiver et al., 1992).

$\mathrm{H}_{2} \mathrm{~S}$ presence may also affect the activity of enzymes involved in photosynthetic $\mathrm{CO}_{2}$ fixation and photosynthetic electron transport (Oliva and Steubing, 1976; Coyne and Bingham, 1978; De Kok et al., 1983a; Taylor and Selvidge, 1984). In isolated spinach chloroplasts $\mathrm{H}_{2} \mathrm{~S}$ exposure inhibited the photoreduction of $\mathrm{NADP}^{+}$and upon illumination it initiated oxygen uptake by the chloroplasts (De Kok et al., 1983a). Sulfide-induced oxygen uptake by chloroplasts was sensitive to the herbicide DCMU (3-(3,4-dichlorophenyl)1,1-dimethylurea) and prevented by the addition of superoxide dismutase to the chloroplast suspension. This indicated that sulfide was oxidized by chloroplasts, its oxidation being initiated by superoxide formed upon illumination at the reducing side of photosystem I (De Kok et al., 1983a). Nevertheless, reductions in photosynthesis are unlikely to be the primary basis of $\mathrm{H}_{2} \mathrm{~S}$ toxicity, since generally in intact plants photosynthesis was only reduced after prolonged exposure to toxic $\mathrm{H}_{2} \mathrm{~S}$ concentrations (Maas et al., 1987a, 1988; De Kok, 1989, 1990).

There is a large variation in $\mathrm{H}_{2} \mathrm{~S}$ susceptibility between species as well as between cultivars of the same species. Whereas continuous exposure to $0.03 \mu \mathrm{L} \mathrm{L}^{-1} \mathrm{H}_{2} \mathrm{~S}$ (a level realistic for regions with industrial or agricultural pollution) negatively affected the growth of susceptible plants (e.g., various spinach cultivars), it stimulated the growth of several other plants on sulfur-sufficient soils [e.g., lettuce (Lactuca sativa), alfalfa (Medicago sativa), and sugar beet (Beta vulgaris); Thompson and Kats, 1978; De Kok, 1989, 1990]. Moreover, whereas in some plants (e.g., lettuce, sugar beet, and common grape vine; Vitis vinifera), visible leaf injury developed upon prolonged exposure to $0.3 \mu \mathrm{L} \mathrm{L}^{-1} \mathrm{H}_{2} \mathrm{~S}$ (a level realistic for areas nearby, e.g., volcanoes), other plants remained unaffected (Thompson and Kats, 1978; De Kok, 1989, 1990). A small number of plants could actually tolerate $\mathrm{H}_{2} \mathrm{~S}$ levels as high as $20 \mu \mathrm{L}^{-1}$ [e.g., maiden silvergrass (Miscanthus sinensis), which inhabits zones very close to volcanoes; Mudd, 1979]. However, at higher $\mathrm{H}_{2} \mathrm{~S}$ levels, all plants quickly developed severe leaf necrosis and rapidly started wilting (Mudd, 1979).

Variation in susceptibility to the negative effects of $\mathrm{H}_{2} \mathrm{~S}$ may partly be associated with differences in the impact of $\mathrm{H}_{2} \mathrm{~S}$ on energy homeostasis. The in vitro cytochrome $c$ oxidase activity was less affected by $\mathrm{H}_{2} \mathrm{~S}$ exposure in flooding-tolerant than in flooding-sensitive species (Martin and Maricle, 2015). Flooding can induce $\mathrm{H}_{2} \mathrm{~S}$ formation in soils, which may 
explain this variation (Martin and Maricle, 2015). Furthermore, in spinach, the more susceptible a plant was for $\mathrm{H}_{2} \mathrm{~S}$, the more the in vitro NADH oxidation capacity of shoots was decreased upon $\mathrm{H}_{2} \mathrm{~S}$ exposure (Maas and De Kok, 1988). In addition, in experiments with other plant species in which growth was not affected by $\mathrm{H}_{2} \mathrm{~S}$ presence, also the in vitro NADH-oxidation capacity was not affected (Stulen et al., 1990). Differences in $\mathrm{H}_{2} \mathrm{~S}$ tolerance could also be related to differences in plant morphology. In general, dicots appeared to be more susceptible to atmospheric $\mathrm{H}_{2} \mathrm{~S}$ than monocots (Stulen et al., 1990, 2000). In monocots, $\mathrm{H}_{2} \mathrm{~S}$ can hardly penetrate the shoot meristem, because the meristem is sheltered by a whorl of leaves (Stulen et al., 1990, 2000). This may cause monocots to be relatively $\mathrm{H}_{2} \mathrm{~S}$ tolerant, since carefully uncovering the shoot meristem of maize (Zea mays) increased its susceptibility to $\mathrm{H}_{2} \mathrm{~S}$ (Stulen et al., 1990, 2000). Whereas this uncovering did not affect the elongation rate of leaves, it delayed the initial leaf development from the meristem and it triggered cell deformations as well as chromosomal irregularities inside the meristem (Stulen et al., 1990, 2000). Notably, it remains elusive if other morphological traits (e.g., traits associated with leaf anatomy) also explain variation in $\mathrm{H}_{2} \mathrm{~S}$ phytotoxicity. Furthermore, it remains elusive if lifehistory traits (e.g., being annual or perennial) contribute to this variation. However, by contrast, it has been observed that variation in $\mathrm{H}_{2} \mathrm{~S}$ phytotoxicity is not directly interrelated to the capacity of a plant to metabolize sulfide in organic compounds (see the next section).

\section{IMPACT OF $\mathrm{H}_{2} \mathrm{~S}$ ON PLANT SULFUR METABOLISM}

Besides reducing growth and survival, plants may also benefit from the presence of atmospheric $\mathrm{H}_{2} \mathrm{~S}$. Since sulfide is a substrate for cysteine synthesis, the gas can be used to synthesize proteins and other organic compounds (De Kok et al., 2007, 2009; Koralewska et al., 2008). Plants can even grow with atmospheric $\mathrm{H}_{2} \mathrm{~S}$ as the only sulfur source (viz. in the absence of root sulfate supply; Buchner et al., 2004; Aghajanzadeh et al., 2016). Atmospheric $\mathrm{H}_{2} \mathrm{~S}$ levels of $0.06 \mu \mathrm{L}^{-1}$ were already sufficient to fully cover the organic sulfur requirement of curly kale (Brassica oleracea; Buchner et al., 2004). Since curly kale is characterized by an extraordinary high sulfur demand, $\mathrm{H}_{2} \mathrm{~S}$ levels realistic for polluted regions (e.g., regions with volcanic activity or intensive animal farming) may significantly contribute to the sulfur requirement of plants in general (Aghajanzadeh et al., 2014, 2015, 2016).

Typically, a significant part of absorbed $\mathrm{H}_{2} \mathrm{~S}$ (up to 30\%) can be revealed in plants as water-soluble non-protein thiols (De Kok, 1990; Poortinga and De Kok, 1997). In shoots the content of these metabolites rapidly and strongly increases upon $\mathrm{H}_{2} \mathrm{~S}$ exposure (De Kok et al., 1983b, 1985; Maas et al., 1985; Poortinga and De Kok, 1997; Riemenschneider et al., 2005; Shahbaz et al., 2013). In the absence of atmospheric $\mathrm{H}_{2} \mathrm{~S}$, watersoluble non-protein thiols constitute $2-4 \%$ of total sulfur present in tissues (Noctor et al., 2012). Generally, glutathione is the most abundant water-soluble non-protein thiol with its content accounting for more than $90 \%$ of the total water-soluble non-protein thiol pool (Noctor et al., 2012). Glutathione is synthesized from cysteine in a two-step process. Cysteine first reacts with glutamate to yield $\gamma$-glutamylcysteine, which subsequently reacts with glycine to yield glutathione (Hawkesford and De Kok, 2006).

Depending on the species and cultivar, $\mathrm{H}_{2} \mathrm{~S}$ exposure increased shoot water-soluble non-protein thiol levels up to five-fold (De Kok et al., 1983b, 1985; Maas et al., 1985; Poortinga and De Kok, 1997; Riemenschneider et al., 2005; Shahbaz et al., 2013). Generally, thiol accumulations were stronger at higher atmospheric $\mathrm{H}_{2} \mathrm{~S}$ levels and the accumulations were not affected by plant age, exposure temperature or the applied light regime (De Kok, 1990). Thiol levels often started to increase within one or $2 \mathrm{~h}$ after the onset of $\mathrm{H}_{2} \mathrm{~S}$ exposure and maximum thiol levels were usually reached after one or 2 days of exposure, independent from the applied $\mathrm{H}_{2} \mathrm{~S}$ concentration (De Kok et al., 1985; Maas et al., 1987b,c; Stuiver et al., 1992; Poortinga and De Kok, 1997). Generally, thiol accumulations could not solely be attributed to enhanced glutathione levels. For instance, a 12-h exposure of different plant species to $0.25 \mu \mathrm{l} \mathrm{L} \mathrm{L}^{-1} \mathrm{H}_{2} \mathrm{~S}$ resulted not only in a two- to three-fold increase in shoot glutathione content, but also in a 8 - to 37 -fold increase in shoot cysteine content (Buwalda et al., 1988, 1993, 1994). Additionally, in the dark, $\mathrm{H}_{2} \mathrm{~S}$ exposure resulted in an accumulation of $\gamma$-glutamylcysteine (up to 20-fold) due to a limitation in glycine availability, which was caused by the absence of photorespiration in the dark (Buwalda et al., 1988, 1993). However, upon transition to the light, accumulated $\gamma$-glutamylcysteine rapidly disappeared as it was metabolized into glutathione (Buwalda et al., 1988, 1993).

Besides altering shoot thiol pools, $\mathrm{H}_{2} \mathrm{~S}$ exposure occasionally also alters root thiol pools. However, upon $\mathrm{H}_{2} \mathrm{~S}$ fumigation root thiol pools usually increased significantly less than shoot thiol pools (maximum two-fold) and the increases could often fully be ascribed to enhanced glutathione levels (De Kok et al., 1997; Poortinga and De Kok, 1997; Stuiver and De Kok, 1997; Tausz et al., 1998; Westerman et al., 2000a). In general, glutathione is predominantly present in plants in its reduced form (e.g., in spinach leaves $>84 \%$; De Kok et al., 1986). In spinach, the ratio between reduced and oxidized glutathione as well as the activity of glutathione reductase were not substantially altered by exposure to $0.25 \mu \mathrm{L}^{-1} \mathrm{H}_{2} \mathrm{~S}$ (De Kok et al., 1986; Tausz et al., 1998).

After termination of $\mathrm{H}_{2} \mathrm{~S}$ exposure, thiol levels decrease. In spinach, cysteine and glutathione levels in shoots decreased simultaneously (De Kok et al., 1985, 1986; Maas et al., 1987b; Buwalda et al., 1994). Moreover, a transition from dark to light immediately after the end of $\mathrm{H}_{2} \mathrm{~S}$ exposure resulted in a decrease in accumulated $\gamma$-glutamylcysteine and a simultaneous increase in glutathione, after which both cysteine and glutathione contents decreased at similar rates (Buwalda et al., 1994). Independent from the $\mathrm{H}_{2} \mathrm{~S}$ concentration that plants were exposed to, thiol levels restored to the levels of unexposed plants within 1 or 2 days (Buwalda et al., 1994). In spinach, 
decreases in thiol levels were not associated with the foliar emission of $\mathrm{H}_{2} \mathrm{~S}$, indicating that desulfhydration of cysteine was not involved in the loss of thiols (De Kok, 1989, 1990). Apparently, accumulated thiols were rapidly metabolized in other compounds.

It is yet unclear why $\mathrm{H}_{2} \mathrm{~S}$ exposure strongly enhances the size of the thiol pool. $\mathrm{H}_{2} \mathrm{~S}$ may partly be metabolized in cysteine and glutathione in another subcellular compartment than sulfate taken up by the root (viz. in the mitochondria and/or cytosol instead of the chloroplasts). In this way, the metabolism of atmospheric $\mathrm{H}_{2} \mathrm{~S}$ could be beyond the control of existing regulatory feedback mechanisms (Hesse et al., 1997; Saito et al., 1997).

It may be hypothesized that variation in the rate of sulfide incorporation in cysteine, glutathione, and other organic compounds (partly) explains variation in $\mathrm{H}_{2} \mathrm{~S}$ tolerance between plants. However, there is no relation between the $\mathrm{H}_{2} \mathrm{~S}$ uptake kinetics and the $\mathrm{H}_{2} \mathrm{~S}$ susceptibility of plants (viz. $\mathrm{H}_{2} \mathrm{~S}$ phytotoxicity; De Kok et al., 1989, 1998, 2002). Moreover, whereas in thale cress (Arabidopsis thaliana) OAS-TL knock-out mutants differed in leaf cysteine and glutathione concentrations from wild-type plants (when exposed to atmospheric $\mathrm{H}_{2} \mathrm{~S}$ concentrations up to $1 \mu \mathrm{L} \mathrm{L}^{-1}$ ), leaf sulfide concentrations and sulfide tolerance were not different (Birke et al., 2015). Seemingly, the metabolism of sulfide in organic compounds is not involved in the detoxification of absorbed $\mathrm{H}_{2} \mathrm{~S}$. It is thus unlikely that differences in the capacity to metabolize $\mathrm{H}_{2} \mathrm{~S}$ explain differences in the phytotoxicity of $\mathrm{H}_{2} \mathrm{~S}$.

It is also unlikely that changes in the size and composition of the thiol pool are directly explaining the phytotoxicity of $\mathrm{H}_{2} \mathrm{~S}$. Enhanced glutathione levels may potentially deregulate the activity of various enzymes and cysteine may possibly react with metabolic aldehydes (Rennenberg, 1981). Nevertheless, various plants (especially monocots) can tolerate strongly elevated shoot cysteine and glutathione levels in the presence of $\mathrm{H}_{2} \mathrm{~S}$ without any negative impact on biomass production, even after prolonged $\mathrm{H}_{2} \mathrm{~S}$ exposure (De Kok, 1989, 1990; Stulen et al., 1990, 2000). In this perspective, it is noteworthy that enhanced glutathione levels may actually also be beneficial for plants. Glutathione has antioxidant properties and elevated glutathione levels may consequently increase the tolerance of plants to environmental stress (Noctor et al., 2012). However, the physiological significance of increased glutathione levels for plant stress protection remains elusive. Exposure of Chinese cabbage (Brassica pekinensis) to copper reduced biomass production (Shahbaz et al., 2014). The copper tolerance of Chinese cabbage was not affected by fumigation with subtoxic $\mathrm{H}_{2} \mathrm{~S}$ levels, even though this strongly enhanced water-soluble non-protein thiol levels (Shahbaz et al., 2014). Furthermore, in maize, the increased thiol levels upon subtoxic $\mathrm{H}_{2} \mathrm{~S}$ fumigation could not counteract the negative impact of salinity on growth (Ausma et al., 2017). Finally, exposure to subtoxic $\mathrm{H}_{2} \mathrm{~S}$ levels did not affect the freezing tolerance of the foliage of winter wheat (Stuiver et al., 1992).

Besides affecting water-soluble non-protein thiol levels, $\mathrm{H}_{2} \mathrm{~S}$ exposure may affect the levels of other sulfur metabolites.
For instance, in onion (Allium cepa) $\mathrm{H}_{2} \mathrm{~S}$ exposure resulted in an accumulation of secondary sulfur compounds ( $v i z$. alliins or their precursors) in the shoot (Durenkamp et al., 2005). Similar to the thiol accumulations, onion could show strongly elevated levels of these compounds without any negative growth effects (Durenkamp et al., 2005). Thale cress accumulated thiosulfate in the shoot upon exposure to a high $\mathrm{H}_{2} \mathrm{~S}$ level ( $1 \mu \mathrm{L} \mathrm{L}^{-1}$; Birke et al., 2015). However, by contrast, exposure to a lower $\mathrm{H}_{2} \mathrm{~S}$ concentration $\left(0.25 \mu \mathrm{L} \mathrm{L}^{-1}\right)$ did not affect the thiosulfate content of several crop species (Buwalda et al., 1993). This suggests that thiosulfate formation is likely also not connected to the phytotoxicity of $\mathrm{H}_{2} \mathrm{~S}$. In some species, $\mathrm{H}_{2} \mathrm{~S}$ exposure resulted in increased shoot sulfate levels (Durenkamp and De Kok, 2002, 2004, 2005; Durenkamp et al., $2005,2007)$. Sulfate accumulation presumably occurs in the vacuole and is, therefore, probably likewise not involved in $\mathrm{H}_{2} \mathrm{~S}$ toxicity (Durenkamp et al., 2005). Enhanced sulfate levels upon $\mathrm{H}_{2} \mathrm{~S}$ exposure may be caused by the degradation of excessively accumulated organic sulfur compounds and/or by the oxidation of absorbed $\mathrm{H}_{2} \mathrm{~S}$ (via sulfide oxidases or via non-enzymatic processes; Durenkamp et al., 2005). Alternatively, it may be caused by a poor regulatory control of $\mathrm{H}_{2} \mathrm{~S}$ over the uptake and assimilation of sulfate (Durenkamp et al., 2005). However, in a plethora of tested plants, viz. common duckweed (Lemna minor), spinach, tobacco (Nicotiana tabacum), and Brassica species, there was a good regulatory control of $\mathrm{H}_{2} \mathrm{~S}$ over the metabolism of sulfate: in these plants $\mathrm{H}_{2} \mathrm{~S}$ absorbance downregulated sulfate uptake and assimilation (Brunold and Erismann, 1975; Herschbach et al., 1995a,b; De Kok et al., 2002). The background of this phenomenon has most extensively been investigated in Brassica seedlings.

\section{IMPACT OF $\mathrm{H}_{2} \mathrm{~S}$ ON THE UPTAKE AND ASSIMILATION OF SULFATE IN BRASSICA}

The genus Brassica contains various agriculturally relevant crops. Brassica species are characterized by a high content of secondary sulfur compounds (viz. glucosinolates), leading to an extraordinary high sulfur demand for growth (Aghajanzadeh et al., 2014, 2015). Additionally, Brassica species are characterized by a high tolerance to atmospheric $\mathrm{H}_{2} \mathrm{~S}$. Biomass production of Brassica seedlings was only significantly reduced upon prolonged exposure to $\geq 0.4 \mu \mathrm{L} \mathrm{L}^{-1}$ $\mathrm{H}_{2} \mathrm{~S}$ (Westerman et al., 2000a).

Similar to observations for other species, in Brassica, cysteine and glutathione levels increased in the shoot upon $\mathrm{H}_{2} \mathrm{~S}$ exposure (at $0.8 \mu \mathrm{L} \mathrm{L} \mathrm{H}_{2}^{-1} \mathrm{~S}$, approximately 12 - and 3.5-fold, respectively), whereas their content in the root was hardly affected (De Kok et al., 2000; Buchner et al., 2004; Koralewska et al., 2008). In Brassica, $\mathrm{H}_{2} \mathrm{~S}$ fumigation did additionally hardly affect the composition and size of the glucosinolate pool (Aghajanzadeh et al., 2014, 2015).

Brassica species may switch from sulfate taken up by the root to $\mathrm{H}_{2} \mathrm{~S}$ taken up by the shoot as sulfur source (De Kok et al., 1997, 2000; Westerman et al., 2000a,b; Buchner et al., 2004; 
Koralewska et al., 2008). If these species were grown on a sulfate-rich medium, $\mathrm{H}_{2} \mathrm{~S}$ exposure caused a partial downregulation in the activity of transporters involved in root sulfate uptake and sulfate distribution to the shoot (Figure 2; De Kok et al., 1997, 1998, 2000; Westerman et al., 2000a,b; Buchner et al., 2004; Koralewska et al., 2008). This downregulation occurred within a few days after the onset of $\mathrm{H}_{2} \mathrm{~S}$ exposure and the extent of the downregulation was dependent on the applied $\mathrm{H}_{2} \mathrm{~S}$ concentration (Westerman et al., 2000a). However, in curly kale, this downregulation was never greater than $60 \%$ (reached at $0.2 \mu \mathrm{L} \mathrm{L}^{-1} \mathrm{H}_{2} \mathrm{~S}$; Westerman et al., 2000a). Higher repressions appeared unnecessary, since in curly kale the organic sulfur fraction constitutes approximately $60 \%$ of total sulfur, whereas sulfate makes up for the other 40\% (De Kok et al., 2000; Westerman et al., 2000a). Consequently, the total sulfur and sulfate content of Brassica were usually hardly affected by $\mathrm{H}_{2} \mathrm{~S}$ fumigation (De Kok et al., 1997, 2000; Westerman et al., 2000a,b; Buchner et al., 2004; Koralewska et al., 2008).

Besides repressing sulfate uptake, $\mathrm{H}_{2} \mathrm{~S}$ exposure may lower sulfate assimilation rates (Figure 2). Briefly, during sulfate assimilation, which is located in plastids of both the root and shoot, sulfate is first converted to adenosine 5 '-phosphosulfate (APS) by the enzyme ATP sulfurylase (ATPS; Hawkesford and De Kok, 2006). The majority of APS is

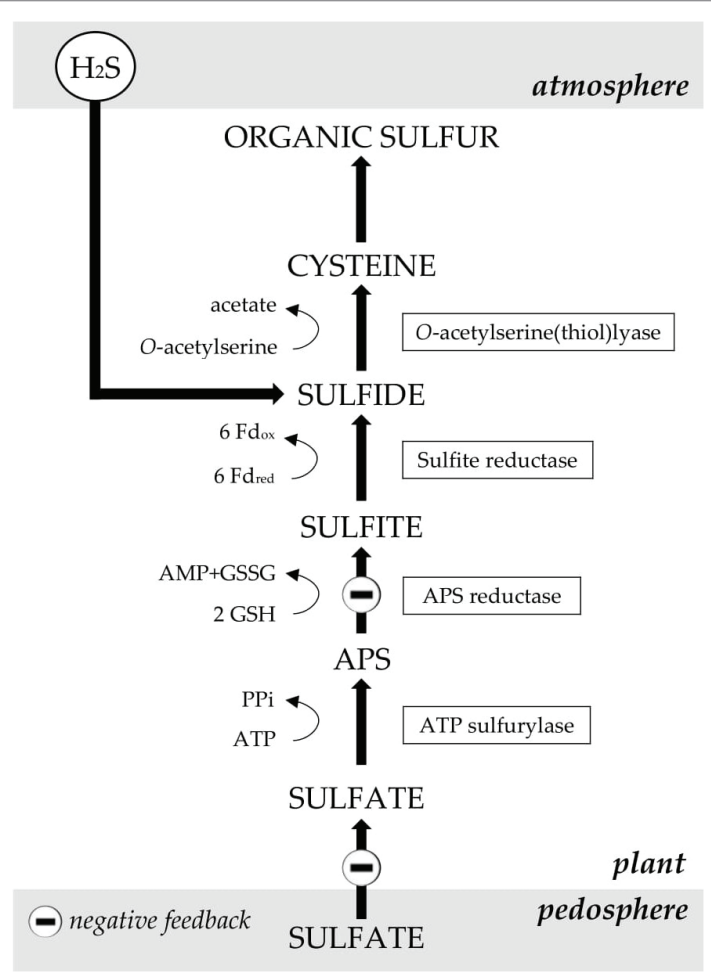

FIGURE 2 | The metabolism of sulfate and the presumed sites in Brassica at which $\mathrm{H}_{2} \mathrm{~S}$ absorbance downregulates sulfate uptake and assimilation (at an ample sulfate supply). APS: adenosine 5'-phosphosulfate; Fdred, Fdox: reduced and oxidized ferrodoxin; GSH, GSSG: reduced and oxidized glutathione. Figure modified after De Kok et al. (2009). subsequently reduced to sulfite by the enzyme APS reductase (APR), which controls the rate of sulfate assimilation (Hawkesford and De Kok, 2006). Sulfite is, in-turn, reduced to sulfide by the enzyme sulfite reductase (SIR; Hawkesford and De Kok, 2006). Finally, sulfide is incorporated in the amino acid cysteine via a reaction with $O$-acetylserine (OAS), catalyzed by OAS-TL (Hawkesford and De Kok, 2006). In Brassica, exposure to $\mathrm{H}_{2} \mathrm{~S}$ decreased both the activity and expression of the enzyme APR in shoots and roots (up to $80 \%$ at $0.8 \mu \mathrm{L} \mathrm{L}^{-1} \mathrm{H}_{2} \mathrm{~S}$ in curly kale; Westerman et al., 2001; De Kok et al., 2002; Aghajanzadeh et al., 2016). The expression and activity of the other enzymes involved in sulfate assimilation viz. ATPS, SIR, and OAS-TL were usually hardly affected by $\mathrm{H}_{2} \mathrm{~S}$ exposure (De Kok et al., 2000; Stuiver and De Kok, 2001; Westerman et al., 2001).

Evidently, in Brassica, there is a good regulatory control of $\mathrm{H}_{2} \mathrm{~S}$ over the utilization of sulfate. However, the shootto-root signals via which $\mathrm{H}_{2} \mathrm{~S}$ downregulates sulfate utilization remain elusive. Though it was proposed that glutathione, sulfate, and/or compounds from nitrogen and carbon metabolism (e.g., amino acids and carbohydrates) may be signal compounds, in Brassica, there were no clear correlations between the levels of these metabolites, the activity of the sulfate transporters and the activity of APR (Westerman et al., 2000a; Koralewska et al., 2008; Shahbaz et al., 2014). Yet, it was evident that root sulfate uptake in Brassica is strongly controlled by the sink capacity (viz. the sulfur status) of the shoot (Koralewska et al., 2009). Furthermore, it was clear that $\mathrm{H}_{2} \mathrm{~S}$ presence downregulates sulfate uptake via transcriptional and posttranscriptional mechanisms (Koralewska et al., 2008). Decreases in sulfate uptake capacity upon $\mathrm{H}_{2} \mathrm{~S}$ fumigation did not directly correlate with decreases in the expression of sulfate transporter $1 ; 2$ (Sultr1;2), which is in Brassica - at an ample sulfate supply - the main transporter responsible for root sulfate uptake (Koralewska et al., 2008).

When Brassica plants are deprived of sulfur, they induce multiple responses enabling an enhanced sulfur use efficiency. Sulfur deprivation rapidly induced the expression of transporters involved in root sulfate uptake, the transport of sulfate to the shoot and the vacuolar exchange of sulfate (Koralewska et al., 2007, 2008). At sulfate-sufficient conditions, generally only Sultr1;2 is responsible for root sulfate uptake (Buchner et al., 2004). However, sulfur deprivation resulted not only in an enhanced expression of Sultr1;2 but also in a strongly enhanced expression of sulfate transporter $1 ; 1$ (Sultr1;1; Buchner et al., 2004; Koralewska et al., 2007, 2008). The upregulated expression of these two sulfate transporters was accompanied by an increased sulfate uptake capacity of the root (Buchner et al., 2004; Koralewska et al., 2007, 2008). Additionally, sulfur deprivation quickly enhanced the expression and activity of APR in both roots and shoots (Koralewska et al., 2007, 2008; Shahbaz et al., 2014; Aghajanzadeh et al., 2016). Moreover, prolonged sulfur deprivation resulted in an altered shoot-to-root biomass partitioning in favor of that of the root (De Kok et al., 1997; Koralewska et al., 2007, 2008). In the absence of a sulfur supply, these changes were 
accompanied by decreases in sulfate and thiol content (De Kok et al., 1997; Buchner et al., 2004; Aghajanzadeh et al., 2016).

If sulfur-deprived Brassica plants were fumigated with $\geq 0.06 \mu \mathrm{L} \mathrm{L}^{-1} \mathrm{H}_{2} \mathrm{~S}$, growth rate generally restored to the level of plants grown in the presence of sulfate (De Kok et al., 1997; Westerman et al., 2000a,b; Buchner et al., 2004; Aghajanzadeh et al., 2016). Additionally, the enhanced expression of APR and the sulfate transporters in the shoot was largely alleviated (Buchner et al., 2004; Aghajanzadeh et al., 2016). The levels of sulfate in these plants remained low, but the water-soluble non-protein thiol content of the shoot restored to the level of sulfate-sufficient plants (though the level in the roots remained slightly lower; Buchner et al., 2004; Aghajanzadeh et al., 2016). This confirmed that at atmospheric $\mathrm{H}_{2} \mathrm{~S}$ levels $\geq 0.06 \mu \mathrm{L} \mathrm{L}^{-1}$ foliarly absorbed sulfide could fully replace sulfate taken up by the root as sulfur source for growth (De Kok et al., 1997; Westerman et al., 2000a,b; Buchner et al., 2004; Aghajanzadeh et al., 2016). Nevertheless, atmospheric $\mathrm{H}_{2} \mathrm{~S}$ exposure of sulfur-deprived plants had little effect on the expression of APR in the root (Buchner et al., 2004; Koralewska et al., 2008; Shahbaz et al., 2014). Furthermore, the expression of Sultr1;1 and Sultr1;2 as well as the sulfate uptake capacity of sulfur-deprived $\mathrm{H}_{2} \mathrm{~S}$-fumigated plants were similar to those of sulfur-deprived plants (Buchner et al., 2004; Koralewska et al., 2008). In addition, the decrease in shoot-to-root biomass partitioning remained largely unaffected (Koralewska et al., 2008). Apparently, when no sulfate is present in the root environment, there is a poor shoot-to-root signaling for the regulation of sulfate utilization in Brassica. This suggests that the uptake and subsequent metabolism of sulfate in Brassica are at least partly controlled by the sulfate concentration in the root environment (besides the sulfur status of the plant itself).

\section{CONCLUDING REMARKS}

The impact of atmospheric $\mathrm{H}_{2} \mathrm{~S}$ on vegetation is paradoxical. On the one hand, $\mathrm{H}_{2} \mathrm{~S}$ presence may negatively affect plant growth and survival. On the other hand, plants can use the gas as a sulfur source for growth. $\mathrm{H}_{2} \mathrm{~S}$ levels found in polluted regions can significantly contribute to the sulfur demand of plants. There is no relation between the rate of $\mathrm{H}_{2} \mathrm{~S}$ metabolism in organic compounds and the $\mathrm{H}_{2} \mathrm{~S}$ susceptibility of plants, which suggests that metabolizing $\mathrm{H}_{2} \mathrm{~S}$ does not constitute a strategy to detoxify absorbed sulfide. By contrast, there may be a strong relation between the rate of $\mathrm{H}_{2} \mathrm{~S}$ metabolism and the rate of sulfate metabolism. The uptake and metabolism of $\mathrm{H}_{2} \mathrm{~S}$ may strongly downregulate the uptake and metabolism of sulfate.

Studies with Brassica have clarified the background of this downregulation. Simultaneously, these investigations illustrated that $\mathrm{H}_{2} \mathrm{~S}$ fumigation may be a useful tool for studying the regulation of sulfur homeostasis in plants. $\mathrm{H}_{2} \mathrm{~S}$ exposure induces changes in the expression and activity of enzymes involved in sulfate metabolism. Moreover, it alters the levels of sulfur metabolites. However, at subtoxic $\mathrm{H}_{2} \mathrm{~S}$ concentrations, biomass production is not affected. Therefore, at subtoxic $\mathrm{H}_{2} \mathrm{~S}$ concentrations, changes in metabolic status are not the consequence of changes in growth ( $v i z$. the result of growth concentration or dilution), but instead the direct consequence of changes in sulfur utilization. Thus, relating changes in, e.g., metabolite content to changes in enzyme expression and activity can be used to unravel signal transduction pathways that control sulfur homeostasis.

In this way, $\mathrm{H}_{2} \mathrm{~S}$ fumigation may not only further clarify the regulation of sulfur metabolism in Brassica, but also the regulation of sulfur metabolism in other plants. For instance, it may clarify the regulation of sulfate uptake in monocots, in which Sultr1;1 appears to be mainly responsible for the primary uptake of sulfate (instead of Sultr1;2 as in Brassica; Buchner et al., 2010). Moreover, fumigation studies may help to elucidate the regulation of sulfate assimilation in $\mathrm{C}_{4}$ plants. Research with the genus Flaveria, which contains $\mathrm{C}_{3}$ and $\mathrm{C}_{4}$ species, indicated that $\mathrm{C}_{4}$ species may have a higher demand for reduced sulfur than $\mathrm{C}_{3}$ species and that sulfate assimilation in $\mathrm{C}_{4}$ species may have shifted to the roots compared to $\mathrm{C}_{3}$ species (Gerlich et al., 2018).

The application of subtoxic $\mathrm{H}_{2} \mathrm{~S}$ levels may additionally help to clarify the physiological significance of sulfur in plants. Analogous to its function in animal physiology, it has been suggested that endogenous sulfide might also in plants function as a signal molecule that modulates plant immunity, senescence, and various other processes (reviewed by Li et al., 2016; Aroca et al., 2018; Hancock, 2018). However, in several studies that addressed the role of endogenous sulfide, plants were cultivated under suboptimal conditions (e.g., under low light intensities) and/or exposed to relatively high concentrations of sodium hydrosulfide (NaHS). If NaHS is added to a nutrient or tissue incubation solution at neutral $\mathrm{pH}$, it will result in a short-term burst of $\mathrm{H}_{2} \mathrm{~S}$, followed by the release of $\mathrm{H}_{2} \mathrm{~S}$ into the atmosphere (Lee et al., 2011). This means that plants are briefly exposed to relatively high $\mathrm{H}_{2} \mathrm{~S}$ levels in both the root and shoot environment, which may not only be phytotoxic, but which also may interfere with the regulation of sulfur homeostasis (De Kok et al., 2007; Martin and Maricle, 2015). Evidently, $\mathrm{H}_{2} \mathrm{~S}$ fumigation of plants provides another way to study the physiological significance of endogenous sulfide as a signal molecule. Foliar $\mathrm{H}_{2} \mathrm{~S}$ application may also be useful to investigate if organic sulfur compounds modulate physiological processes, since upon $\mathrm{H}_{2} \mathrm{~S}$ fumigation the content of several of these compounds may be strongly altered.

\section{AUTHOR CONTRIBUTIONS}

TA and LK have both made substantial, direct, and intellectual contributions to this work. Both approved it for publication.

\section{FUNDING}

The research of TA is funded by The Netherlands Organization for Scientific Research (NWO) via ALW Graduate Program Grant 2017.015. 


\section{REFERENCES}

Aghajanzadeh, T., Hawkesford, M. J., and De Kok, L. J. (2014). The significance of glucosinolates for sulfur storage in Brassicaceae seedlings. Front. Plant Sci. 5:704. doi: 10.3389/fpls.2014.00704

Aghajanzadeh, T., Hawkesford, M. J., and De Kok, L. J. (2016). Atmospheric $\mathrm{H}_{2} \mathrm{~S}$ and $\mathrm{SO}_{2}$ as sulfur sources for Brassica juncea and Brassica rapa: regulation of sulfur uptake and assimilation. Environ. Exp. Bot. 124, 1-10. doi: 10.1016/j. envexpbot.2015.12.001

Aghajanzadeh, T., Kopriva, S., Hawkesford, M. J., Koprivova, A., and De Kok, L. J. (2015). Atmospheric $\mathrm{H}_{2} \mathrm{~S}$ and $\mathrm{SO}_{2}$ as sulfur source for Brassica juncea and Brassica rapa: impact on the glucosinolate composition. Front. Plant Sci. 6:924. doi: 10.3389/fpls.2015.00924

Aroca, A., Gotor, C., and Romero, L. C. (2018). Hydrogen sulfide signaling in plants: emerging roles of protein persulfidation. Front. Plant Sci. 9:1369. doi: $10.3389 / \mathrm{fpls} .2018 .01369$

Ausma, T., Parmar, S., Hawkesford, M. J., and De Kok, L. J. (2017). "Impact of atmospheric $\mathrm{H}_{2} \mathrm{~S}$, salinity and anoxia on sulfur metabolism in Zea mays" in Sulfur metabolism in higher plants: Fundamental, environmental and agricultural aspects. eds. L. J. De Kok, M. J. Hawkesford, S. H. Haneklaus, and E. Schnug (Dordrecht: Springer), 93-101.

Baillie, C. K., Kaufholdt, D., Karpinski, L. H., Schreiber, V., Hänsch, S., Evers, C., et al. (2016). Detoxification of volcanic sulfur surplus in planta: three different strategies of survival. Environ. Exp. Bot. 126, 44-54. doi: 10.1016/j. envexpbot.2016.02.007

Beauchamp, R. O., Bus, J. S., Popp, J. A., Boreiko, C. J., and Andjelkovich, D. A. (1984). A critical review of the literature on hydrogen sulfide toxicity. CRC Crit. Rev. Toxicol. 13, 25-97. doi: 10.3109/10408448409029321

Birke, H., De Kok, L. J., Wirtz, M., and Hell, R. (2015). The role of compartmentspecific cysteine synthesis for sulfur homeostasis during $\mathrm{H}_{2} \mathrm{~S}$ exposure in Arabidopsis. Plant Cell Physiol. 56, 358-367. doi: 10.1093/pcp/pcu166

Bloem, E., Haneklaus, S., Salac, I., Wickenhauser, P., and Schnug, E. (2007). Facts and fiction about sulfur metabolism in relation to plant-pathogen interactions. Plant Biol. 9, 596-607. doi: 10.1055/s-2007-965420

Brunold, C., and Erismann, K. H. (1975). $\mathrm{H}_{2} \mathrm{~S}$ as sulfur source in Lemna minor L: II. Direct incorporation into cysteine and inhibition of sulfate assimilation. Experientia 31, 508-510. doi: 10.1007/BF01932426

Buchner, P., Parmar, S., Kriegel, A., Carpentier, M., and Hawkesford, M. J. (2010). The sulfate transporter family in wheat: tissue-specific gene expression in relation to nutrition. Mol. Plant 3, 374-389. doi: 10.1093/mp/ssp119

Buchner, P., Stuiver, C. E. E., Westerman, S., Wirtz, M., Hell, R., Hawkesford, M. J., et al. (2004). Regulation of sulfate uptake and expression of sulfate transporter genes in Brassica oleracea L. as affected by atmospheric $\mathrm{H}_{2} \mathrm{~S}$ and pedospheric sulfate nutrition. Plant Physiol. 136, 3396-3408. doi: 10.1104/pp.104.046441

Buwalda, F., De Kok, L. J., and Stulen, I. (1992). The flux of atmospheric $\mathrm{H}_{2} \mathrm{~S}$ to spinach leaves can be affected by the supply of $O$-acetylserine. Phyton $32,15-18$.

Buwalda, F., De Kok, L. J., and Stulen, I. (1993). Effects of atmospheric $\mathrm{H}_{2} \mathrm{~S}$ on thiol composition of crop plants. J. Plant Physiol. 142, 281-285. doi: 10.1016/S0176-1617(11)80423-2

Buwalda, F., De Kok, L. J., and Stulen, I. (1994). The pool of water-soluble non-protein thiols is not regulated within narrow limits in spinach leaves exposed to atmospheric $\mathrm{H}_{2} \mathrm{~S}$. Plant Physiol. Biochem. 32, 533-537.

Buwalda, F., De Kok, L. J., Stulen, I., and Kuiper, P. J. C. (1988). Cysteine $\gamma$-glutamyl-cysteine and glutathione contents of spinach leaves as affected by darkness and application of excess sulfur. Physiol. Plant. 74, 663-668. doi: 10.1111/j.1399-3054.1988.tb02033.x

Carn, S. H., Fioletov, V. E., McLinden, C. A., Li, C., and Krotkov, N. A. (2017). A decade of global volcanic $\mathrm{SO}_{2}$ emissions measured from space. Sci. Rep. 7:44095. doi: 10.1038/srep44095

Cope, D. M., and Spedding, D. J. (1982). Hydrogen sulphide uptake by vegetation. Atmos. Environ. 16, 349-353. doi: 10.1016/0004-6981(82)90452-8

Coyne, P. I., and Bingham, G. E. (1978). Photosynthesis and stomatal light responses in snap beans exposed to hydrogen sulfide and ozone. J. Air Pollut. Control Assoc. 28, 1119-1123. doi: 10.1080/00022470.1978.10470715

De Bruyn, W. J., Swartz, E., Hu, J. H., Shorter, J. A., Davidovits, P., Worsnop, D. R., et al. (1995). Henry's law solubilities and Śtchenow coefficients for biogenic reduced sulfur species obtained from gas-liquid uptake measurements. J. Geophys. Res. 100, 7245-7251. doi: 10.1029/95JD00217

De Kok, L. J. (1989). Responses of sulfur metabolism in plants to atmospheric hydrogen sulfide. Phyton 29, 189-201.

De Kok, L. J. (1990). "Sulfur metabolism in plants exposed to atmospheric sulfur" in Sulfur nutrition and sulfur assimilation in higher plants. eds. H. Rennenberg, C. Brunold, L. J. De Kok, and I. Stulen (The Hague: SPB Academic Publishers), 111-130.

De Kok, L. J., Bosma, W., Maas, F. M., and Kuiper, P. J. C. (1985). The effect of short-term $\mathrm{H}_{2} \mathrm{~S}$ fumigation on water-soluble sulfhydryl compounds and glutathione levels in spinach. Plant Cell Environ. 8, 189-194. doi: 10.1111/ 1365-3040.ep11604605

De Kok, L. J., Durenkamp, M., Yang, L., and Stulen, I. (2007). "Atmospheric sulfur" in Sulfur in plants: An ecological perspective. eds. M. J. Hawkesford and L. J. De Kok (Berlin: Springer), 91-106.

De Kok, L. J., Maas, F. M., Godeke, J., Haaksma, A. B., and Kuiper, P. J. C. (1986). Glutathione a tripeptide which may function as a temporary storage of excessive reduced sulphur in $\mathrm{H}_{2} \mathrm{~S}$ fumigated spinach plants. Plant Soil 91, 349-352. doi: 10.1007/BF02198121

De Kok, L. J., Rennenberg, H., and Kuiper, P. J. C. (1991). The internal resistance in spinach shoots to atmospheric $\mathrm{H}_{2} \mathrm{~S}$ deposition is determined by metabolism processes. Plant Physiol. Biochem. 29, 463-470.

De Kok, L. J., Stahl, K., and Rennenberg, H. (1989). Fluxes of atmospheric hydrogen sulfide to plant shoots. New Phytol. 112, 533-542. doi: 10.1111/ j.1469-8137.1989.tb00348.x

De Kok, L. J., Stuiver, C. E. E., Rubinigg, M., Westerman, S., and Grill, D. (1997). Impact of atmospheric sulfur deposition on sulfur metabolism in plants: $\mathrm{H}_{2} \mathrm{~S}$ as sulfur source for sulfur deprived Brassica oleracea L. Bot. Acta 110, 411-419. doi: 10.1111/j.1438-8677.1997.tb00657.x

De Kok, L. J., Stuiver, C. E. E., and Stulen, I. (1998). "Impact of atmospheric $\mathrm{H}_{2} \mathrm{~S}$ on plants" in Responses of plant metabolism to air pollution and global change. eds. L. J. De Kok and I. Stulen (Leiden: Backhuys Publishers), 41-63.

De Kok, L. J., Stuiver, C. E. E., Westerman, S., and Stulen, I. (2000). "Atmospheric $\mathrm{H}_{2} \mathrm{~S}$ as plant sulfur source: interaction with pedospheric sulfur nutrition a case study with Brassica oleracea L." in Sulfur nutrition and sulfur assimilation in higher plants: Molecular, biochemical and physiological aspects. eds. C. Brunold, H. Rennenberg, L. J. De Kok, I. Stulen, and J. C. Davidian (Bern: Paul Haupt), 41-55.

De Kok, L. J., Stuiver, C. E. E., Westerman, S., and Stulen, I. (2002). "Elevated levels of hydrogen sulfide in the plant environment: nutrient or toxin" in Air pollution and biotechnology in plants. eds. K. Omasa, H. Saji, S. Youssefian, and N. Kondo (Tokyo: Springer-Verlag), 201-213.

De Kok, L. J., and Tausz, M. (2001). "The role of glutathione in plant reaction and adaptation to air pollutants" in Significance of glutathione to plant adaptation to the environment. eds. D. Grill, M. Tausz, and L. J. De Kok (Dordrecht: Kluwer Academic), 185-201.

De Kok, L. J., Thompson, C. R., and Kuiper, P. J. C. (1983a). Sulfide-induced oxygen uptake by isolated spinach chloroplasts catalyzed by photosynthetic electron transport. Physiol. Plant. 59, 19-22. doi: 10.1111/j.1399-3054.1983. tb06564.x

De Kok, L. J., Thompson, C. R., Mudd, J. B., and Kats, G. (1983b). Effect of $\mathrm{H}_{2} \mathrm{~S}$ fumigation on water-soluble sulfhydryl compounds in shoots of crop plants. Z. Pflanzenphysiol. 111, 85-89. doi: 10.1016/S0044-328X(83)80076-2

De Kok, L. J., Yang, L., Stuiver, C. E. E., and Stulen, I. (2009). "Negative vs. positive functional plant responses to air pollution: a study establishing cause-effect relationships to $\mathrm{SO}_{2}$ and $\mathrm{H}_{2} \mathrm{~S}$ " in Air quality and ecological impacts, relating sources to effects. ed. A. Legge (Amsterdam: Elsevier), 121-134.

Durenkamp, M., and De Kok, L. J. (2002). The impact of atmospheric $\mathrm{H}_{2} \mathrm{~S}$ on growth and sulfur metabolism of Allium cepa L. Phyton 42, 55-63.

Durenkamp, M., and De Kok, L. J. (2004). Impact of pedospheric and atmospheric sulphur nutrition on sulphur metabolism of Allium cepa L. a species with a potential sink capacity for secondary sulphur compounds. J. Exp. Bot. 55, 1821-1830. doi: 10.1093/jxb/erh187

Durenkamp, M., and De Kok, L. J. (2005). Low levels of $\mathrm{H}_{2} \mathrm{~S}$ may replace sulfate as sulfur source in sulfate-deprived onion. Phyton 45, 69-77.

Durenkamp, M., De Kok, L. J., and Kopriva, S. (2007). Adenosine 5' phosphosulphate reductase is regulated differently in Allium cepa L. and 
Brassica oleracea L. upon exposure to $\mathrm{H}_{2} \mathrm{~S}$. J. Exp. Bot. 58, 1571-1579. doi: 10.1093/jxb/erm031

Durenkamp, M., Posthumus, F. S., Stuiver, C. E. E., and De Kok, L. J. (2005). "Metabolism of atmospheric sulfur gases in onion" in Plant responses to air pollution and global change. eds. K. Omasa, I. Nouchi, and L. J. De Kok (Tokyo: Springer), 3-11.

Ernst, W. H. O. (1997). "Life-history syndromes and the ecology of plants from high sulphur-habitats" in Sulphur metabolism in higher plants: Molecular ecophysiological and nutritional aspects. eds. W. J. Cram, L. J. De Kok, I. Stulen, C. Brunold, and H. Rennenberg (Leiden: Backhuys Publishers), 131-146.

Fioletov, V. E., McLinden, C. A., Krotkov, N., Li, C., Joiner, J., Theys, N., et al. (2016). A global catalogue of large $\mathrm{SO}_{2}$ sources and emissions derived from the ozone monitoring system. Atmos. Chem. Phys. 16, 11497-11519. doi: 10.5194/acp-16-11497-2016

Gerlich, S. C., Walker, B. J., Krueger, S., and Kopriva, S. (2018). Sulfate metabolism in $\mathrm{C}_{4}$ Flaveria species is controlled by the root and connected to serine biosynthesis. Plant Physiol. 178, 565-582. doi: 10.1104/pp.18.00520

Hancock, J. T. (2018). Hydrogen sulfide and environmental stresses. Environ. Exp. Bot. 161, 50-56. doi: 10.1016/j.envexpbot.2018.08.034

Haneklaus, S., Bloem, S., and Schnug, E. (2007). "Sulfur and plant disease" in Mineral nutrition and plant diseases. eds. L. Datnoff, W. Elmer, and D. Huber (St. Paul: APS Press), 101-118.

Hawkesford, M. J., and De Kok, L. J. (2006). Managing sulphur metabolism in plants. Plant Cell Environ. 29, 382-395. doi: 10.1111/j.1365-3040.2005.01470.x

Hell, R., Jost, R., Berkowitz, O., and Wirtz, M. (2002). Molecular and biochemical analysis of the enzymes of cysteine biosynthesis in the plant Arabidopsis thaliana. Amino Acids 22, 245-257. doi: 10.1007/s007260200012

Herschbach, C., De Kok, L. J., and Rennenberg, H. (1995a). Net uptake of sulphate and its transport to the shoot in spinach plants fumigated with $\mathrm{H}_{2} \mathrm{~S}$ or $\mathrm{SO}_{2}$ : does atmospheric sulphur affect the 'inter-organ' regulation of sulphur nutrition? Bot. Acta 108, 41-46. doi: 10.1111/j.1438-8677.1995. tb00829.x

Herschbach, C., De Kok, L. J., and Rennenberg, H. (1995b). Net uptake of sulphate and its transport to the shoot in tobacco plants fumigated with $\mathrm{H}_{2} \mathrm{~S}$ or $\mathrm{SO}_{2}$. Plant Soil 175, 75-84. doi: 10.1007/BF02413012

Hesse, H., Lipke, J., Altman, T., and Hoefgen, R. (1997). "Expression analysis and subcellular localization of cysteine synthase isoforms from Arabidopis thaliana" in Sulphur metabolism in higher plants: Molecular ecophysiological and nutritional aspects. eds. W. J. Cram, L. J. De Kok, I. Stulen, C. Brunold, and H. Rennenberg (Leiden: Backhuys Publishers), 227-230.

Kanda, K. I., and Tsuruta, H. (1995). Emissions of sulfur gases from various types of terrestrial higher plants. Soil Sci. Plant Nutr. 41, 321-328. doi: 10.1080/00380768.1995.10419589

Kellogg, W. W., Cadle, R. D., Allen, E. R., Lazrus, A. L., and Martell, E. A. (1972). The sulfur cycle. Science 175, 587-596. doi: 10.1126/science.175.4022.587

Klimont, Z., Smith, S. J., and Cofala, J. (2013). The last decade of global anthropogenic sulfur dioxide: 2000-2011 emissions. Environ. Res. Lett. 8:014003. doi: $10.1088 / 1748-9326 / 8 / 1 / 014003$

Koralewska, A., Posthumus, F. S., Stuiver, C. E. E., Buchner, P., and De Kok, L. J. (2007). The characteristic high sulfate content in Brassica oleracea is controlled by the expression and activity of sulfate transporters. Plant Biol. 9, 654-661. doi: $10.1055 / \mathrm{s}-2007-965438$

Koralewska, A., Stuiver, C. E. E., Posthumus, F. S., De Kok, L. J., and Hawkesford, M. J. (2009). "The up-regulated sulfate uptake capacity, but not the expression of sulfate transporters is strictly controlled by the sink capacity in curly kale" in Sulfur metabolism in plants: Regulatory aspects, significance of sulfur in the food chain, agriculture and the environment. eds. A. Sirko, L. J. De Kok, S. Haneklaus, M. J. Hawkesford, H. Rennenberg, K. Saito, E. Schnug, and I. Stulen (Leiden: Backhuys Publishers), 61-68.

Koralewska, A., Stuiver, C. E. E., Posthumus, F. S., Kopriva, S., Hawkesford, M. J., and De Kok, L. J. (2008). Regulation of sulfate uptake, expression of the sulfate transporters Sultr1,1 and Sultr1,2, and APS reductase in Chinese cabbage (Brassica pekinensis) as affected by atmospheric $\mathrm{H}_{2} \mathrm{~S}$ nutrition and sulfate deprivation. Funct. Plant Biol. 35, 318-327. doi: 10.1071/FP07283

Lee, Z. W., Zhou, J., Chen, C. S., Zhao, Y., Tan, C. H., Li, L., et al. (2011). The slow-releasing hydrogen sulfide donor, GYY4137, exhibits novel anticancer effects in vitro and in vivo. PLoS One 6:e21077. doi: 10.1371/journal. pone. 0021077
Lendzian, K. L. (1984). "Permeability of plant cuticles to gaseous air pollutants" in Gaseous air pollutants and plant metabolism. eds. M. J. Koziol, and F. R. Whatley (London: Butterworths), 77-81.

Li, Z. G., Min, X., and Zhou, Z. H. (2016). Hydrogen sulfide: a signal molecule in plant cross-adaptation. Front. Plant Sci. 26:1621. doi: 10.3389/fpls.2016.01621

Maas, F. M., and De Kok, L. J. (1988). In vitro NADH oxidation as an early indicator for growth reductions in spinach exposed to $\mathrm{H}_{2} \mathrm{~S}$ in the ambient air. Plant Cell Physiol. 29, 523-526. doi: 10.1093/oxfordjournals.pcp.a077524

Maas, F. M., De Kok, L. J., Hoffmann, I., and Kuiper, P. J. C. (1987a). Plant responses to $\mathrm{H}_{2} \mathrm{~S}$ and $\mathrm{SO}_{2}$ fumigation. I. Effects on growth, transpiration and sulfur content of spinach. Physiol. Plant. 70, 713-721. doi: 10.1111/j.13993054.1987.tb04329.x

Maas, F. M., De Kok, L. J., and Kuiper, P. J. C. (1985). The effect of $\mathrm{H}_{2} \mathrm{~S}$ fumigation on various spinach (Spinacia oleracea L.) cultivars. Relation between growth inhibition and accumulation of sulphur compounds in the plant. J. Plant Physiol. 119, 219-226. doi: 10.1016/S0176-1617(85)80181-4

Maas, F. M., De Kok, L. J., Peters, J. L., and Kuiper, P. J. C. (1987c). A comparative study on the effects of $\mathrm{H}_{2} \mathrm{~S}$ and $\mathrm{SO}_{2}$ fumigation on the growth and accumulation of sulfate and sulfhydryl compounds in Trifolium pratense L., Glycine max Merr. and Phaseolus vulgaris L. J. Exp. Bot. 38, 1459-1469. doi: $10.1093 / \mathrm{jxb} / 38.9 .1459$

Maas, F. M., De Kok, L. J., Strik-Timmer, W., and Kuiper, P. J. C. (1987b). Plant responses to $\mathrm{H}_{2} \mathrm{~S}$ and $\mathrm{SO}_{2}$ fumigation. II. Differences in metabolism of $\mathrm{H}_{2} \mathrm{~S}$ and $\mathrm{SO}_{2}$ in spinach. Physiol. Plant. 70, 722-728. doi: 10.1111/j.1399-3054.1987.tb04330.x

Maas, F. M., van Loo, E. N., and Van Hasselt, P. R. (1988). Effect of long-term $\mathrm{H}_{2} \mathrm{~S}$ fumigation on photosynthesis in spinach. Correlation between $\mathrm{CO}_{2}$ fixation and chlorophyll a fluorescence. Physiol. Plant. 72, 77-83. doi: 10.1111/j.1399-3054.1988.tb06625.x

Martin, N. M., and Maricle, B. R. (2015). Species-specific enzymatic tolerance of sulfide toxicity in plant roots. Plant Physiol. Biochem. 88, 36-41. doi: 10.1016/j.plaphy.2015.01.007

Mathai, J. C., Missner, A., Kügler, P., Saparov, S. M., Zeidel, M. L., Lee, J. K., et al. (2009). No facilitator required for membrane transport of hydrogen sulfide. Proc. Natl. Acad. Sci. USA 106, 16633-16638. doi: 10.1073/ pnas.0902952106

Mudd, J. B. (1979). "Effects on vegetation and aquatic animals" in Hydrogen sulfide. ed. Assembly of Life Sciences (U.S.) Subcommittee on Hydrogen Sulfide (Baltimore: University Park Press), 67-79.

Nobel, P. S. (1983). Biophysical plant physiology and ecology. (San Francisco: Freemann and Co.).

Noctor, G., Mhamdi, A., Chaouch, S., Han, Y., Neukermans, J., Marquez-Garcia, B., et al. (2012). Glutathione in plants: an integrated overview. Plant Cell Environ. 35, 454-484. doi: 10.1111/j.1365-3040.2011.02400.x

Oliva, M., and Steubing, L. (1976). Untersuchungen über der beeinflussung von photosynthese, respiration and wasserhaushalt durch $\mathrm{H}_{2} \mathrm{~S}$ bei Spinacia oleracea. Angew. Bot. 50, 1-17.

Perraud, V., Horne, J. R., Martinez, A. S., Kalinowski, J., Meinardi, S., Dawson, M. L., et al. (2015). The future of airborne sulfur-containing particles in the absence of fossil fuel sulfur dioxide emissions. Proc. Natl. Acad. Sci. USA 112, 13514-13519. doi: 10.1073/pnas.1510743112

Poortinga, A. M., and De Kok, L. J. (1997). "Uptake of atmospheric $\mathrm{H}_{2} \mathrm{~S}$ by Spinacia oleracea L. and consequences for thiol content and composition in shoots and roots" in Sulphur metabolism in higher plants: Molecular, ecophysiological and nutritional aspects. eds. W. J. Cram, L. J. De Kok, I. Stulen, C. Brunold, and H. Rennenberg (Leiden: Backhuys Publishers), 285-288.

Rennenberg, H. (1981). Differences in the use of cysteine and glutathione as sulfur source in photoheterotrophic tobacco suspension cultures. Z. Pflanzenphysiol. 105, 31-40. doi: 10.1016/S0044-328X(81)80005-0

Rennenberg, H. (1984). The fate of excess sulfur in higher plants. Ann. Rev. Plant Physiol. 35, 121-153. doi: 10.1146/annurev.pp.35.060184.001005

Rennenberg, H., Huber, B., Schröder, P., Stahl, K., Haunold, W., Georgii, H. W., et al. (1990). Emission of volatile sulfur compounds from spruce trees. Plant Physiol. 92, 560-564. doi: 10.1104/pp.92.3.560

Riahi, S., and Rowley, C. N. (2014). Why can sulfide permeate cell membranes? J. Am. Chem. Soc. 136, 15111-15113. doi: 10.1021/ja508063s

Riemenschneider, A., Nikiforova, V., Hoefgen, R., De Kok, L. J., and Papenbrock, J. (2005). Impact of elevated $\mathrm{H}_{2} \mathrm{~S}$ on metabolite levels, activity of enzymes 
and expression of genes involved in cysteine metabolism. Plant Physiol. Biochem. 43, 473-483. doi: 10.1016/j.plaphy.2005.04.001

Saito, K., Takahashi, H., Takagi, Y., Inoue, K., and Nojim, M. (1997). "Molecular characterization and regulation of cysteine synthase and serine acetyltransferase from plants" in Sulphur metabolism in higher plants: Molecular, ecophysiological and nutritional aspects. eds. W. J. Cram, L. J. De Kok, I. Stulen, C. Brunold, and H. Rennenberg (Leiden: Backhuys Publishers), 235-238.

Schnug, E. (1997). "Significance of sulphur for the quality of domesticated plants" in Sulphur metabolism in higher plants: Molecular, ecophysiological and nutritional aspects. eds. W. J. Cram, L. J. De Kok, I. Stulen, C. Brunold, and H. Rennenberg (Leiden: Backhuys Publishers), 109-130.

Schröder, P. (1993). "Plants as sources of atmospheric sulfur" in Sulfur nutrition and assimilation in higher plants: Regulatory, agricultural and environmental aspects. eds. L. J. De Kok, I. Stulen, H. Rennenberg, C. Brunold, and W. E. Rauser (The Hague: SPB Academic Publishing), 253-270.

Schulte, M., Herschbach, C., and Rennenberg, H. (1997). "Long term effects of naturally elevated $\mathrm{CO}_{2}, \mathrm{H}_{2} \mathrm{~S}$ and $\mathrm{SO}_{2}$ on sulphur allocation in Quercus" in Sulphur metabolism in higher plants: Molecular, ecophysiological and nutritional aspects. eds. W. J. Cram, L. J. De Kok, I. Stulen, C. Brunold, and H. Rennenberg (Leiden: Backhuys Publishers), 289-291.

Schütz, B., De Kok, L. J., and Rennenberg, H. (1991). Thiol accumulation and cysteine desulfhydrase activity in $\mathrm{H}_{2} \mathrm{~S}$-fumigated leaves and leaf homogenates of cucurbit plants. Plant Cell Physiol. 32, 733-736. doi: 10.1093/oxfordjournals. pcp.a078138

Shahbaz, M., Parmar, S., Stuiver, C. E. E., Hawkesford, M. J., and De Kok, L. J. (2013). Copper toxicity and sulfur metabolism in Chinese cabbage are affected by UV radiation. Environ. Exp. Bot. 88, 60-70. doi: 10.1016/j. envexpbot.2012.04.007

Shahbaz, M., Stuiver, C. E. E., Posthumus, F. S., Parmar, S., Hawkesford, M. J., and De Kok, L. J. (2014). Copper toxicity in Chinese cabbage is not influenced by plant sulphur status, but affects sulphur metabolism-related gene expression and the suggested regulatory metabolites. Plant Biol. 16, 68-78. doi: 10.1111/ plb.12019

Sipilä, M., Berndt, T., Petäjä, T., Brus, D., Vanhanen, J., Stratmann, F., et al. (2010). The role of sulfuric acid in atmospheric nucleation. Science 327, 1243-1246. doi: 10.1126/science.1180315

Slatt, B. J., Natusch, D. F. S., Prospero, J. M., and Savoie, D. L. (1978). Hydrogen sulfide in the atmosphere of the northern equatorial Atlantic ocean and its relation to the global sulfur cycle. Atmos. Environ. 12, 981-991. doi: 10.1016/ 0004-6981(78)90342-6

Stern, D. I. (2005). Global sulfur emissions from 1850 to 2000. Chemosphere 58, 163-175. doi: 10.1016/j.chemosphere.2004.08.022

Stuiver, C. E. E., and De Kok, L. J. (1997). "Atmospheric $\mathrm{H}_{2} \mathrm{~S}$ as sulphur source for sulphur deprived Brassica oleracea L and Hordeum vulgare L." in Sulphur metabolism in higher plants: Molecular, ecophysiological and nutritional aspects. eds. W. J. Cram, L. J. De Kok, I. Stulen, C. Brunold, and H. Rennenberg (Leiden: Backhuys Publishers), 293-294.

Stuiver, C. E. E., and De Kok, L. J. (2001). Atmospheric $\mathrm{H}_{2} \mathrm{~S}$ as sulfur source for Brassica oleracea: kinetics of $\mathrm{H}_{2} \mathrm{~S}$ uptake and activity of $\mathrm{O}$-acetylserine (thiol)lyase as affected by sulfur nutrition. Environ. Exp. Bot. 46, 29-36. doi: 10.1016/S0098-8472(01)00080-6

Stuiver, C. E. E., De Kok, L. J., and Kuiper, P. J. C. (1992). Freezing tolerance and biochemical changes in wheat shoots as affected by $\mathrm{H}_{2} \mathrm{~S}$ fumigation. Plant Physiol. Biochem. 30, 47-55.
Stulen, I., and De Kok, L. J. (1993). "Whole plant regulation of sulfate uptake and metabolism - a theoretical approach and comparison with current ideas on regulation of nitrogen metabolism" in Sulfur nutrition and assimilation in higher plants: Regulatory, agricultural and environmental aspects. eds. L. J. De Kok, I. Stulen, H. Rennenberg, C. Brunold, and W. E. Rauser (The Hague: SPB Academic Publishing), 77-91.

Stulen, I., Posthumus, F. S., Amâncio, S., and De Kok, L. J. (1990). Why is $\mathrm{H}_{2} \mathrm{~S}$ not phytotoxic in monocots? Physiol. Plant. 7:123.

Stulen, I., Posthumus, F. S., Amâncio, S., Masselink-Beltman, I., Müller, M., and De Kok, L. J. (2000). "Mechanism of $\mathrm{H}_{2} \mathrm{~S}$ phytotoxicity" in Sulfur nutrition and sulfur assimilation in higher plants: Molecular, biochemical and physiological aspects. eds. C. Brunold, H. Rennenberg, L. J. De Kok, I. Stulen, and J. C. Davidian (Bern: Paul Haupt), 381-383.

Tausz, M., Van der Kooij, T. A. W., Müller, M., De Kok, L. J., and Grill, D. (1998). "Uptake and metabolism of oxidized and reduced sulfur pollutants by spruce trees" in Responses of plant metabolism to air pollution and global change. eds. L. J. De Kok, and I. Stulen (Leiden: Backhuys Publishers), 457-460.

Taylor, G. E., and Selvidge, W. J. (1984). Phytotoxicity in bush bean of five sulfur-containing gases released from advanced fossil energy technologies. J. Environ. Qual. 13, 224-230. doi: 10.2134/jeq1984.00472425001300020010x

Thompson, C. R., and Kats, G. (1978). Effect of continuous $\mathrm{H}_{2} \mathrm{~S}$ fumigation on crop and forest plants. Environ. Sci. Technol. 12, 550-553. doi: 10.1021/ es60141a001

Trudinger, P. A. (1986). "Chemistry of the sulfur cycle" in Sulfur in agriculture. ed. M. A. Tabatabai (Madison: American Society of Agronomy), 1-22.

Van der Kooij, T. A. W., and De Kok, L. J. (1998). "Kinetics of deposition of $\mathrm{SO}_{2}$ and $\mathrm{H}_{2} \mathrm{~S}$ to shoots of Arabidopsis thaliana L." in Responses of plant metabolism to air pollution and global change. eds. L. J. De Kok and I. Stulen (Leiden: Backhuys Publishers), 479-481.

Watts, S. F. (2000). The mass budgets of carbonyl sulfide, dimethyl sulfide, carbon disulfide and hydrogen sulfide. Atmos. Environ. 34, 761-779. doi: $10.1016 /$ S1352-2310(99)00342-8

Westerman, S., De Kok, L. J., Stuiver, C. E. E., and Stulen, I. (2000a). Interaction between metabolism of atmospheric $\mathrm{H}_{2} \mathrm{~S}$ in the shoot and sulfate uptake by the roots of curly kale (Brassica oleracea). Physiol. Plant. 109, 443-449. doi: 10.1034/j.1399-3054.2000.100411.x

Westerman, S., Stulen, I., Suter, M., Brunold, C., and De Kok, L. J. (2001). Atmospheric $\mathrm{H}_{2} \mathrm{~S}$ as sulfur source for Brassica oleracea: consequences for the activity of the enzymes of the assimilatory sulfate reduction pathway. Plant Physiol. Biochem. 39, 425-432. doi: 10.1016/S0981-9428(01)01258-X

Westerman, S., Weidner, W., De Kok, L. J., and Stulen, I. (2000b). Effect of $\mathrm{H}_{2} \mathrm{~S}$ exposure on ${ }^{35} \mathrm{~S}$-sulfate uptake, transport and utilization in curly kale. Phyton 40, 293-302.

Conflict of Interest Statement: The authors declare that the research was conducted in the absence of any commercial or financial relationships that could be construed as a potential conflict of interest.

Copyright (c) 2019 Ausma and De Kok. This is an open-access article distributed under the terms of the Creative Commons Attribution License (CC BY). The use, distribution or reproduction in other forums is permitted, provided the original author(s) and the copyright owner(s) are credited and that the original publication in this journal is cited, in accordance with accepted academic practice. No use, distribution or reproduction is permitted which does not comply with these terms. 